\title{
Book Reviews: Thinking About Cultural Resource Management: Essays From the Edge
}

Robert Cast

Unknown

Follow this and additional works at: https://scholarworks.sfasu.edu/ita

Part of the American Material Culture Commons, Archaeological Anthropology Commons, Environmental Studies Commons, Other American Studies Commons, Other Arts and Humanities Commons, Other History of Art, Architecture, and Archaeology Commons, and the United States History Commons

Tell us how this article helped you.

This Article is brought to you for free and open access by the Center for Regional Heritage Research at SFA ScholarWorks. It has been accepted for inclusion in Index of Texas Archaeology: Open Access Gray Literature from the Lone Star State by an authorized editor of SFA ScholarWorks. For more information, please contact cdsscholarworks@sfasu.edu. 
Book Reviews: Thinking About Cultural Resource Management: Essays From the Edge

\section{Creative Commons License}

(c) (1) (9)

This work is licensed under a Creative Commons Attribution-NonCommercial 4.0 International License 


\section{Book Reviews}

Thinking About Cultural Resource Management: Essays From the Edge, by Thomas F. King, 2002. AltaMira Press, Walnut Creek, California. xix + 196 pp.

Reviewed by Robert Cast, Caddo Tribal Historic Preservation Officer

The Guru of Section 106 has just compiled a book of essays that every CRM professional, archeologist, anthropologist, historic preservationist, environmentalist (have I covered all the pertinent "ists"?), and Native Americans concerned with preserving, protecting, and managing historic properties should read. There is even a nifty glossary of terms for those readers who may not be familiar with the compliance lingo that goes along with Section 106, the National Environmental Protection Act, the Native American Graves Protection and Repatriation Act, and the whole host of other federal laws related to historic preservation.

In this collection, Dr. King, or "Dr. Phil of National Preservation Institute" as I like to refer to him, has organized the book into four separate sections that address a number of issues of interest to at least one of the disciplines mentioned above, plus he devotes an entire section of the book to "Thinking About Indigenous Issues." The titles of the chapters alone are enough to catch one's eye and entice the reader to follow King on his journey to the edge. Such chapters as: "Process vs. Preservation: A False Dichotomy," "What Should We Consult About," and "Archeo-Bias: Recognition and Prevention," are not only catchy titles but address valid, complex, quandries that those of us who work in the bureaucratic mire of cultural resource management regulations and compliance are faced with every day. King offers us a series of reallife problems in the compliance world, plenty of real-world examples, and as always, a variety of unique alternatives to solving the problems.

One of the underlying themes throughout this entire book of essays, and stated openly in the chapter "Process vs. Preservation: A False Dichotomy," is the simple fact that while King, being an advocate of "good process," understands that with all the procedural regulations and laws that we have in place, these laws and processes are merely words on paper. The process is only as good as the people who perform it, and only as good as the people working within the process. Through consultation, these people can bring their own personalities and life experiences to the otherwise stale, question-ridden, full-of-flaws laws. King states: "You need processes for deciding what's important, how justified actions are that may affect important things, what alternatives are available to achieve a proposed action's purposes, and what to do about the effects of justified alternatives." This is the crux of the Section 106 process in a single sentence.

The chapter entitled, "What Should We Consult About?," reinforces this central theme. King is not so naive as to think that the process of Section 106, as it is traditionally practiced across the United States of America, is a good thing, or a viable practice in considering all views of any number of consulting parties. This fine-line between process and practice is where most of the compliance problems occur, and only by "thinking outside the box" are we able to address them in a manner that will bring closure, compliance, and usually some kind of compromise to otherwise unsolvable scenarios within the conundrum of the compliance process. 
As the Tribal Historic Preservation Officer for the Caddo Nation of Oklahoma, I am all too familiar with these issues. For example, in King's essay "Archeo-Bias: Recognition and Prevention" he gives us his definition of what "archeo-bias" is along with a list of some of its character traits. One of the symptoms listed is: A tendency to "write off" areas that have been "disturbed." I must admit, as King readily does, that I too have been both "victim" and "victimizer" by thinking only in terms of archeology when dealing with consultations regarding historic properties. However, I have seen over and over how thinking only in these terms can be unjust in relating how the Caddo people perceive certain projects. One of the projects that readily comes to mind is when human remains affiliated to the Caddo were discovered while workers dug a pipeline at a water treatment plant that had been built in the 1950s. In the real world, the construction work that had been on going would never have been reviewed by the State Historic Preservation Office (SHPO) since the whole area had been predetermined to be far too "disturbed." In the end, the Caddo Nation, city officials, the archeological contractor, and the SHPO's office consulted together and reached an agreement on what needed to be done.

One of the other listed tendencies Dr. King mentions is: Considering the significance of properties largely with reference to their information content-if they may contain interesting data they're significant; if they probably don't, they aren't. In my job, I must consider what is important and significant only in terms of what the Caddo Nation sees as important and significant. As an example, Caddo Lake and its surrounding areas are significant to the Caddo people. It is also significant to archeologists and environmentalists. No doubt it is significant to the people living there presently; however, the Caddo people do not need the information that archeologists or environmentalists have obtained to tell them that this is a significant place. Moreover, if the area had never contained any archeological information, it would still be significant to the Caddo. If Caddo Lake, god forbid, was entirely drained, filled-in, and had a Wet-n-Wild Water Park built in its place, it would not lose any of the significance it has to the Caddo Nation. That in a sense is the difference between an area being significant for the information it provides archeologists and significance of location to tribal beliefs and history. In the words of Dr. King: "And if you're an archeologist, be of good cheer; archeobias can be cured. Rigorously review your own writing, and your own thinking, for evidence of archeo-bias, and try to weed it out...Like it or not, CRM isn't just applied archeology."

This book of essays, whether you agree with him or not, has something for everyone. As for me, I tend to think of things in terms of food and eating. I read this book in my biased, preconceived point-of-view as a book of recipes for the practice of CRM. My mother was a wonderful cook and rarely ever used a recipe but cooked meals "by taste." In following the procedural regulations of Section 106, and the plethora of laws that govern what shall and shall not be done, Dr. King asks us to ask ourselves what we are trying to accomplish. He asks us to not simply follow the recipes of all these compliance procedures but look at the ways in which we may add a little spice to the process. This can be done in a variety of ways, such as the use of Programmatic Agreements, Memoranda of Agreements, and involving a wide array of interested parties in the consultation process. Like my mother, Dr. King knows the proof is in the pudding. 